\title{
AZ ÁTMENET avagy Veszprém megye a rendszerváltás időszakában
}

\author{
Oläh M. (szerk.) (1995) OOK Press Kft. Veszprém, 640 o.
}

Már külső megjelenésében is érdeklödést keltő könyvvel találkozik az olvasó, ha kézbe veszi $A z$ átmenet avagy Veszprém megye a rendszerváltás idöszakában c. könyvet. Kiadója a Veszprém Megyei Önkormányzat Közgyülése, lektorálta Agg Zoltán, Nemes Nagy József és Radics István.

A kötet címében is felvállalt témája az átmenet és a rendszerváltás. Mit értünk $\mathrm{e}$ két fogalom tartalmán? Az „átmenet” az államszocializmus politikai és a tervgazdálkodás újraelosztó rendszerébỏl a politikai szabadság és a piacgazdaság rendjébe való átalakulás hosszú, több évtizedes periódusa. Ez a folyamat a szocialista nagyipar lerombolását, a veszteséget termelö munkahelyek megszüntetését, a mezőgazdasági ártámogatások lebontását jelenti, ami a megyében százezreket sújtó megpróbáltatásokkal jár.

A tudomány nem tekinti a ,rendszerváltás" kifejezést valamiféle univerzális fogalomnak a változások komplex leírására. Magam is szivesebben használom a valós társadalmi-gazdasági-politikai és kulturális folyamatok kifejezésére az ,átmenet" terminust. Arra van szükség, hogy nagyobb távlatokban közelitsük meg a múlt, a jelen és a jövő tendenciáit, ennek a célnak az „átmenet” és az „átalakulás” elnevezés jobban megfelel.

A mủ megszületésének körülményeiről Oláh Miklós szerkesztỏ az elöszóban arról szól, hogy azt az egyre növekvö, kielégítetlen felhasználói igények által megtestesített kihívás indította el. A potenciális felhasználók munkájához nem ált rendelke- zésre elegendő összetételü és mélységü információ a megye társadalmi, gazdasági és infrastrukturális helyzetéröl. Ennek az az oka, hogy a társadalmi átalakulás folyamatában a korábbi gazdasági, társadalomtudományi szellemi mühelyek megszüntek vagy átalakultak, a statisztikai apparátusok ellehetetlenültek, az addig kötelező adatszolgáltatási rendszer felbomlott, szétaprózódott. A változások menetében számos új társadalmi-gazdasági szereplö jelent meg, akiktöl adatszolgáltatást nem kaphatott a közigazgatási és informatikai iroda. Oláh Miklós elmondja, hogy célirányos kutatásokat határoztak el, hogy e fontos korszak mozgásait, változásait dokumentáló adatokat feltárják. A kötet információinak egyik fele cégektől és intézményektöl származik, a többit egyéni kutatók eredeti kutatásai eredményezték.

A hatalmas munkát, melyet a szükség és hiány hozott létre, nagy siker koronázta. Elkészült Veszprém megye történelmi trendekben és maiságában is szinte teljes képe, egy tanulmányok folyamában az olvasó és felhasználó számára kitúnően hasznosítható tény- és tudástár, elemzés. A munka értékét csak növeli, hogy a kutatók - valamennyien szakmájuk ismert müvelöi - azt a nehézséget törekedtek feloldani, hogy a rendelkezésre álló adatok többnyire 1992-vel zárultak.

Imponáló a kötet számszerüsítve is: 31 szerzó (néprajzos, történész, közgazdász, statisztikus, demográfus, politológus, szociológus, geográfus, mérnök, jogász), 23, tanulmány, 640 nagyformátumú oldal, több száz táblázat, ábra, hisztogram, tér- 
kép. A tanulmányok feltárják Veszprém megye gazdasági, demográfiai, tárgyi és szociális infrastrukturális, idegenforgalmi, foglalkoztatási, környezet- és természetvédelmi helyzetét, bemutatják a kőzigazgatási és politikai intézményrendszer változásait.

Szerencsés választás volt, hogy egy országos (némely vonatkozásban a középkelet-európai régióra is kitekintö) szintetizáló bevezetó tanulmány elkészítésére Nemes Nagy József professzort, az ELTE Természettudományi Kara regionális földrajzi tanszékének vezetöjét kérte fel a szerkesztö. A kötet müfaját is ö határozta meg, veszprémisztika, a hungarológia vagy amerikanisztika analógiájára: ,Az egymástól a vizsgált társadalmi problémákat tekintve nagyon eltérỏ tanulmányokat egyértelmü közös alapra helyezi a vizsgálat mindenütt azonos térségi kerete - Veszprém megye". A rendszerváltás fö tartalmát a megyében a már bekövetkezett példátlan gazdasági recesszióban látja, objektív megrázkódtatásaival együtt, $s$ óvatosan megelölegez egyelöre csak elméletileg egy fordulatot a gazdasági növekedésben (fejlödésben). E folyamat során legalább középtávon egy helyreállitási periódus sem kerülhető el. A tudós geográfus felhívja a figyelmet arra, hogy a megye csak durva elemzésre alkalmas, mert az átlagolás eltakarhatja a lényegi folyamatok kistérségi, városkörzeti eltéréseit. A megye gazdasági pozícióit összességében jelenleg kedvezőtlenül érintik a változások, ezért Veszprém megye „...az átlagosnál kedvezőbb helyzetü, de az élmezőnyt alkotó fővárostól és a nyugati térségektől elmaradó helyzetủnek minősíthető". Ezt magam is csak megerősíteni tudom.

Tévesnek tartom ugyanakkor, hogy a regionális fejlettség mérésére a GDP fajlagosának használata alapján Nemes Nagy
József arra a következtetésre jut, hogy a megyék sorrendjében elsö Tolna megye, Veszprém megye pedig a tizedik. Ez csak a felhasznált adatok pontatlansága vagy számítási hiba lehet.

A „nem divatos megye" jelző használata nem szerencsés, mert Veszprém megye turisztikai vonzerejénél (Balaton, Bakony), természeti szépségénél, gazdag kulturális emlékeinél és adottságainál fogva nemzetközi összehasonlításban is jó adottságokkal rendelkezik, egy keresett, vonzó megye. Nem szerencsés a gazdasági dinamizmust a divatos jelzövel felcserélni.

A kötet arról tanúskodik, hogy Veszprém megye annyi sajátos tartalmat hordoz, hogy még ilyen terjedelem mellett is csak töredékes kísérlet, vázlat tud lenni, arra képes "csak", hogy tendenciákat mutasson be, a korábbiakhoz képest másfajta értékrendszer felé közelítsen. Aki ezt a feladatot meg tudta oldani, igazi küldetést teljesitett. Jó példa erre Patka László mủvelödéstörténeti feldolgozása.

A kötet által átfogott időszak az 198919.94 közötti hat év. Mégis helyes volt, hogy a rendszerváltás időszakát megelöző, egyes témákban több évszázadra is visszanyúló előzményeket, a kiindulópontokat is feltárták. Közigazgatás-történeti elözmények, néprajzi, müvelődés- és mủvészettörténeti irrások adnak lehetőséget a tendenciák megismerésére, az új összefüggések, jellegzetességek bemutatására.

A nagy terjedelem ellenére is marad a recenzensnek hiányérzete. Ma, amikor az újrapolgárosodás zajlik a nagy átmenet során, jó lenne tudni, hogyan zajlott Veszprém megyében és milyen jellemzői voltak 1867 és 1948 között a polgárosodás folyamatának.

A könyv legnagyobb érdeme adatgazdagsága, tény- és tárgyszerüsége, mely alkalmas tendenciák bemutatására, követ- 
keztetések levonására. A megyéröl szól, mégis minden község szerepel benne.

A szerkesztő után a legnagyobb feladat hárult Berta Györgyné közgazdász-statisztikusra, aki az egész kötet egyötödét kitevó „Veszprém megye gazdasági szerkezete" és „A megye szociális infrastruktúrája" címú elemzéseket írta meg imponáló szinvonalon.

Mértéktartó, hogy a politikai rendszerváltás kérdésköre mindössze két tanulmányban szerepel. Zongor Gábor, a megyei önkormányzat elnöke a megye közigazgatásának változásait mutatta be igen sok konkrétumot tartalmazó irásában és arra a következtetésre jutott, hogy a stabilitás és a változás elegye érvényesült e területen, de még nem fejeződött be a települési igazgatás és a középszintú igazgatás struktúrájának hosszú távú kiépítése. A másik téma a többpártrendszerủ Veszprém megyei pártélet és pártszerkezet kiépülése és mủködése volt Bánlaki Ildikó és Navracsics Tibor tanulmányában. A szerzők elegendő megbizható írott forrás hiányában információszerzés és pontositás céljából beszélgetéseket folytattak a megyében tevékenykedö pártok vezetőivel. A pártosodást a megkésettséggel jellemzik. A parlamenti és az önkormányzati ciklus felezóévétől (1992) érzékelik a lakosság pesszimizmusának, az ajkai és várpalotai válságövezetekben pedig radikalizmusának növekedését az átalakulással együtt járó növekvỏ anyagi-foglalkoztatási nehézségek miatt, ami az 1994-es választások ismert eredményéhez vezetett.

A mezőgazdaság átalakulásával és annak társadalmi következményeivel há rom tanulmány is foglalkozik. Külön érdekessége a kötetnek, hogy az egyiket a japán Ieda Oszamu, a Hokkaido Egyetem Szláv Kutatóközpontjának (Sapporo) professzora írta, aki kitűnó ismerője a magyar mezögazdaságnak, a magyar szövetkezeti mozgalomnak. Kutatásait 1972 óta végzi e témában. Megkülönböztetett figyelemmel kíséri a rendszerváltást. Veszprém megyében húsz tsz-t elemzett, s kitủnỏ nyelvtudása révén a magyar nyelvũ szakirodalomnak is avatott ismeröje.

Csak sajnálhatjuk, hogy a kapitalizmusba való átmenettel járó társadalmi konfliktusokkal, emberi problémákkal a szerzók nem vagy csak alig foglalkoznak. Pozitiv példa azért van, pl. Holló Miklósnak a közoktatásról szóló dolgozata. A legszínesebb, ugyanakkor a társadalmi problémákat történelmi folyamatosságában leginkább megragadó írás Albert Józsefnek a Veszprémi (Vegyipari) Egyetemről szóló dolgozata, aki arra a konklúzióra jut, hogy „... Veszprémnek a rendszerváltoztatásokkal szerencséje van, legalábbis az egyetemfejlesztést illetően...".

A kötet visszhangja máris nagyon pozitív és méltóan lehet az. Elismerés illeti a szerkesztót, a kiadót, a szerzóket és a lektorokat. Már most érdemes volna gondolkodni azon, hogy 2000-re az átalakulás, a sok újabb változás és a remélt fellendülés folyamatát egy újabb kötetben rögzítenék.

Beszteri Béla 